\title{
A CONSTITUCIONALIDADE DO IMPÔSTO ESTADUAL DE PRODUÇÃO
}

\author{
ARÍZIO DE VIANA \\ Chefe da Divisão da Despesa da Comissão \\ de Orçamento do Ministério da Fazenda

\begin{abstract}
SUMARIO : Impôsto de produção e impôsto de consumo - Impôsto de exploração agrícola e industrial - Impôsto de exportação - Conclusão.
\end{abstract}

Pode-se afirmar, com absoluta segurança, que, nos têrmos da legislação vigente, os Estados têm o direito de criar impostos sôbre a produção de quaisquer utilidades que se verificar em seus próprios territórios. Excetuados o carvão mineral e os combustiveis e lubrificantes líquidos, não há na Constituição brasileira nenhuma disposição que pró́ba expressamente êsse impôsto. Além dos impostos que a Constituição atribui, com exclusividade, aos Estados, compete a êstes criar outros não expressamente vedados. $\mathrm{Na}$ discriminação de rendas em vigor, não se veda, portanto, aos Estados, tributar sua produção.

Impôsto de produção e impôsto de consumo - A hipótese de que o impôsto de produção se confunde com o de consumo - näo obstante a argumentação sustentada por eminentes autoridades - pode ser discutida e afastada com apoio em princípios geralmente aceitos de técnica tributária. Impôsto de consumo é ônus que grava o cbjeto depois de conciuído o ciclo da produção. Grava-o teòricamente, no momento em que abandona o produtor para ser transferido ao adquirente, que vai utilizá-lo. A necessidade fatal de consumi-lo atrai o ônus fiscal. Quem sente essa necessidade e a satisfaz suporta o gravame correspondente. Determinar, porém, o momento exato do início do consumo constitui intransponivel dificuldade para o fisco. Seria necessáric que êste surpreendesse o consumidor na ocasião em que adquirisse o objeto do produtor. Ora, entre um e outro há os comerciantes intermediários. Para tornar efetiva a sua ação arrecadadora, o aparelhamento fiscal teria naturalmente de socorrer-se, como, efetivamente, se socorre, de uma concepção menos abstrata a mais pragmática. A União, por êsse motivo, arrecada êsse tributo, antecipadamente, na fonte de produção. Faz o produtor pagar-lhe o que, sob forma de acréscimo no preço do produto, lhe será, na primeira transação, reembolsado pelo adquirente imediato ou, em última análise, pelo consumidor. Todavia, êste conhecido fenômeno de repercussão do impôsto não the deforma a origem, não the corrompe a essência, não the desfigura a natureza jurídica. $O$ ato material da percussão direta e efetiva, deconrente da forma de cobranģa, não desvirtua a incidência final do tributo, não altera sua característica financeira, nem afeta o objetivo fiscal visado pela lei que o criou.

Por mais variados e diferentes que sejam os impostos, é sabido que êles se acomodam no binômio - diretos e indiretos - segundo onerem a pessoa, o capital e a renda, ou os atos, os fatos e as circunstancias. fissim, por exemplo, o impôsto de consumo grava o fato econômico que consiste em fruir por necessidade bens postos em circulação. $O$ impôsto de produção grava o fato econômico que consiste em confeccionar, fabricar ou explorat, com fins de lucro, bens destinados ao consumo. O impôsto de vendas e consignaçóes grava o fato econômico que consiste em negociar, em transmitir comercialmente bens de indivíduos ou entidades entre si. Os três fatos taxados, as três operações gravadas, se distinguem perfeitamente, ainda que se realizem em tôrno de uma 
só mercadoria. Por conseguinte, ê lícito ao pođer público onerar a produção da mercadoria (pelo impôsto de produção), a transação dos intermediários que exploram sua circulação com fins lucrativos (pelo impôsto de vendas e consignações) e o consumo daqueles que vão utilizá-la na satisfação de uma necessidade humana (pelo impôsto de consumo).

No circuito das atividades econômicas só teòricamente se pode determinar o ponto convencional em que começa a produção ou o consumo. As operações intrínsecas da própria produção envolvem, evidentemente, a utilização e, por conseguinte, $o$ consumo de instalações, matérias primas, fôrça motriz, inteligência e esfôrco muscular. A produção é um imperativo do consumo e vice-versa. Se não houvesse necessidades consuntivas, evidentemente deixariam de existir iniciativas produtoras. Mas, se isto é verdade, mesmo reciprocamente, quando se analisa o fenômeno econômico in abstracto e em função do dinamismo natural das atividades humanas; há que considerar a matéria em seu aspecto estático, sem o que seria impossívl o raciocínio científico. Dá́ a divisão clássica da economia em quatro fases distintas : a produção, a circulação, a distribuição e o consumo. Essa divisão teórica define os fenômenos econômicos e facilita a dedução das leis que os regem. Conseqüentemente, pela caracterização dos fatos sociais, atrai a ação política e financeira do Estado. Se o Estado, como em nosso país, se organiza sob três níveis de govêrno - federal, estadual e municipal - e se a cada um dêstes níveis se atribui uma área de acão, com problemas e encargos específicos, naturalmente se lhes reserva, no estatuto constitucional, o dineito, algumas vêzes exclusivo e outras vêzes facultativo, de tributar, sob diferentes graus e formas, a riqueza e as atividades econômicas nacionais, para que obtenham recursos com que custeiem os serviços que devem prestar à coletividade.

Vários são os sistemas de discriminação tributária. Quando, porêm, a carta constitucional prescreve um dêles, certo ou errado, bom ou inconveniente, justo ou iníquo, não é lícito ao intérprete censurá-lo. Tem, por fôrça, de aceitá-lo tal como o impôs a Constituição. Esta admitiu a existência de impostos de consumo e não fêz referência a impostos de produção, senão excepcionalmente (apenas, as Leis Constitucionais n os 3 e 4 declaram, peremptòriamente, que aos Estados, ao Distrito Federal e aos Municípios fica vedado tributar, direta ou indiretamente, a produção e o comércio, inclusive a distribuição e a exportação, de carvão mineral nacional e de combustiveis e lubrificantes liquidos de qualquer origem). Ora, por fôrça do art. 24 , a Constituição assegura aos Estados o direito de criar outros impostos além dos que atribui à sua competência exclusiva e desde que sejam observadas as proibiçóes e restrições expressamente definidas. Não há, como se viu, proibição expressa para que os Estados tributem a produção ou exploração agrícola e industrial de quaisquer bens com exceção de carvão mineral e dos combustiveis e lubrificantes liquidos. Uma velha regra de hermenêutica aconselha o intérprete a respeitar as palavras técnicas empregadas na lei e nega-lhe o direito de ampliar-lhes ou restringir-lhes o sentido por extensão ou analogia. Onde a Constituição se refere à atividade econômica caracterizada como consumo, emprega a palavra consumo e, quando faz referência à produção, emprega êste vocábulo acompanhado de outros que demonstram, à saciedade, a iritenção de respeitar-lhe o conceito eminentemente técnico. Como acolher, portanto, o argumento de que o impôsto de produção se confunde com o de consumo e que, por conseguinte, sendo êste de competência da União, o Estado, se criasse aquêle, incorreria nơ vício da bitributação? Se prevalecesse tal raciocínio, uma análise meticulosa de tôda a legislação institucional dos tributos no Brasil, baixada pelos três níveis de Govêrno, conduziria à inevitável conclusão de que a bitributação não passa de romântica ilusão constitucional. 
Impôsto de exploração agrícola e industrial - Pela relação e classificação que fêz dos tributos admitidos na especificação da receita dos Estados a Municípios, o Decreto-lei n.o 2.416, de 17-7-1940, reconheceu a existência efetiva do impôsto de exploração agrícola e industrial. Êsse impôsto encontra amparo, como se demonstrou, no art. 24 da Constituição, quanto à competência específica, e no art. $8^{\circ}$, quanto à competência geral, que têm os Estados de custear com seus próprios recursos os serviços e encargos que the estão a exigir o bem-estar, a civilização e o progresso das coletividades regiorais.

Para decretá-lo, não é preciso que o Estado apresente como sucedâneo de um tributo extinto como, por exemplo, a de exportação interestadual. Esta tem sido, aliás, a hipótese freqüentemente invocada por alguns Estados. Com êsse ou outro fundamento financeiro, o que é certo é que, apesar da controvérsia estabelecida, 11 Estados da Federação, a saber : Maranhão, Piauí, Ceará, Rio Grande do Norte, Paraíba, Sergipe, Minas Gerais, Espírito Santo, Rio de Janeiro, Rio Grande do Sul e Goiás, arrecadam em seus territórios impostos sôbre exploração agrícola ou industrial, ou melhor, impostos de produção. Ora, quando um Estado quer reformar sua legislação tributária, a razão suprema que o conduz a assim proceder se apóia mum dos mais flexíveis e legítimos princípios da ciência das finanças - o da máxima conveniência pública. Seu direito de criar novos tributos e, evidentemente, de atrair por meio dêles maiores rendas não deverá sofrer limitações senão na própria capacidade tributária de seus habitantes, da qual é êle o supremo juiz. Quando aumenta a riqueza, mormente numa fase excepcional da história econômica, como esta que atravessamos, lícito é ao Estado aumentar, pela tributação nova ou progressiva, a cota dessa riqueza que proporcionalmente lhe cabe extrair para atender às exigências públicas de maior soma de prestação de serviços.

Impôsto de exportação - Admitamos que haja incidido um Estado no grave êrro político e econômico de ter fomentado a monocultura de um produto e baseado seu sistema tributário no impôsto, ora extinto, de exportação. Não é necessário, porém, reviver o velho drama econômico e fiscal que, desde n Império até nossos dias, vem, freqüentemente, ao cenário da vida pública nacional, para deblaterar a inconveniência dêsse tributo. À fôrça de repetição, tomou foros de indisputável verdade a alegação de que o impôsto de exportação era anti-econômico, porque, encarecendo o produto indigena, impedia que no campo da concorrência internacional aspirasse o país a uma posição comercial de relêvo. Ao contrário, porém, do que a maioria supõe, economistas, que melhor estudaram êste asșunto, demonstraram que, quando o mundo reclamava, eventualmente, um produto de origem colonial, o Brasil comparecia sempre para suprir as exigênoias do mercado; mas, desde que se organizava normalmente a concorrência, o Brasil se eclipsava, sem capacidade de recuperar a antiga posição que suas possibilidades econômicas estariam fadadas a assegurar-lhe com caráter de permanência e prestigio cada vez maiores; assim aconteceu com a borracha, com o açúcar, com o algodão, com o fumo, com - cacau e finalmente com o café; mas, a culpa desta fatalidade econômica, longe de recair sôbre os tributos e, principalmente, sôbre o malfadado impôsto de exportação, recaía exclusivamente na falta de crganização técnica da nossa produção e do comércio com o exterior, porque não contávamos, como ainda hoje não podemos contar, com os mesmos elementos em maquinaria, capital e mão de obra, que asseguram a outros países melhores condições de êxito : preponderância na competição capitalista internacional. Nosso país, infelị̂s mente, ainda continua a desempenhar aquêle papel, que obsarvou NoRMano, "de fornecedor mundial em época de emergência, quando uma deficiência de suprimento eleva os preços e permite a competição de produtos de alto custo". 
Pois bem, o Estado que reconhecesse a inconveniência do impôsto de exportação e o repudiasse não o substituiria por outro de incidência idêntica, sob falsa denominação, quando taxasse a produção de suas riquezas. Evidentemente, êsse Estado não criaria, porém, um impôsto único que gravasse, indiferentemente, tôdas as atividades produtoras. Poderia, ao contrário, instituir um impôsto diversificado, em razão da matéria tributável e em razão do valor do objeto de incidência. Ampararia, pela isenção, os pequenos produtores, que gozam, aliás, dêsse benefício também quanto ao impôsto de vendas e consignações e estimularia, sempre que a economia estadual reclamasse esta atitude, as atividades de vulto, que, por sua alta expressão econômica, proporcionassem os benefícios públicos que frequientemente trazem os grandes empreendimentos. Se, no cômputo geral da arrecadação do novo tributo, o orçamento do Estado se beneficiasse pela entrada de recursos maiores do que os que proporcionava o repudiado impôsto de expistração, nenhuma influência restritiva da ação fiscal poderia decorrer dessa circunstância porque, por outro lado, haveria que levar em conta os encargos cada vez mais onerosos que ao Estado incumbiria desempenhar em favor do progresso de sua população.

Ora, o Estado que assim procedesse não poderia ser acusado de cobrar o impôsto de exportação sob título diferente. Pelo contrário, êle gravaria o fato da produção e não a circunstância (seja permitida a expressão redundante) da saída de produtos para fora de seu território. Pouco importa, conforme se acentuou, que sôbre o mesmo produto se repita, sob modalidades diferentes de incidência, o ônus fiscal. A ação tributária do poder público ficaria reduzida fatalmente à contingência do impôsto único sempre que se procurasse contestar sua legitimidade exclusivamente pelo método de identificação do gravame com a coisa gravada. Não se trata de uma sutileza do direito fiscal, mas de simples observação de princípios fundamentais em que se assenta a teoria geral dos impostos. Já ficou demonstrado, e não é demais repetir, que a percussão do impôsto, ou melhor, o ato efetivo de cobrá-lo nesta cu naquela ocasião, dêste ou daquele contribuinte, por esta ou aquela forma, não the altera a natureza incidencial. No caso em exame, o alvo do tributo é a produção, que pode ser atingido, diretamente, na fonte produtora ou, indiretamente, onde fồ mais cômodo ao Estado e ao contribuinte ajustarem seus interêsses recíprocos.

A variabilidade do impôsto de três em três meses apoiada, por exemplc, 7a revio da pauta dos valores dos produtos, para que sôbre êstes recaísse um ônus, em caso algum excedente de $10 \%$ ad valorem, seria uma sugestão que sòmente poderia acarretar resultados benéficos. Com efeito, fixado o limite máximo do tributo em $10 \%$ sôbre o valor dos produtos, e sendo êsse valor variável (e agora mais que nunca, pela extraordinária flutuação dos preços), o Estado reservar-se-ia o direito de estabelecer pautas trimestrais. Em casos de decréscimo ou acréscimo do valor, o rendimento do impôsto seria proporcionalmente menor ou maior. Não estaria, ainda, D poder público impedido de reduzir, em cada cass, a fôrça do gravame. Sem ultrapassar êste a $10 \%$, poderia ser rebaixado até a isenção, numa escala descendente, que, de acôrdo com os interêsses do Tesouro, dos contribuintes e da economia regional, o Estado houvesse por bem estabelecer. Nessa maleabilidade fiscal só se poderia encontrar benefício para o contribuinte e para a produção; nunca o mais leve temor de insegurança. Fixado o limite máximo do tributo, haveria segurança absoluta de que tal limite não poderia ser excedido. Nenhum obstáculo constituiria êle, portanto, à instalação de novas indústrias. Sòmente em beneficio dos contribuintes e não do Tesouro poderia ser usado - recurso da variabilidade dentro daquele limite, recurso êste que o Estado utilizaria quando julgasse oportuno e conveniente. 
Conclusão - Em conclusão, o impôsto estadual de produção é perfeitamente admissivel, sob o ponto de vista da constitucionalidade. A cada Estado iñcimíitá, entrotantô, examinar os fundamentos financeiros e econômicos que justifiquem a conveniência de sua decretação, em face da capacidade tributária de sua população.

Enquanto, porém, não houver uma reforma tributária, em têrmos nacionais, que proceda a uma revisão completa da legislação fiscal dos três níveis de govêrno, com o fim de simplificar, coordenar e possivelmente uniformizar o processo de cobrança e distribuição equitativa dos tributos, parece justo que os Estados se utilizem de um legítimo recurso, como o impôsto de produção, para que possam aumentar sua receita e ao mesmo tempo proporcionar aos seus habitantes maior soma de bem estar e progresso social. 